\title{
Tax Incentives for Technological Business Innovation in Brazil: The Use of the Good Law - Lei do Bem (Law No. II I96/2005)
}

\author{
Sidirley Fabiani', Roberto Sbragia ${ }^{2}$
}

\begin{abstract}
The Research \& Development \& technological innovation (RD\&l) are among the main sources for the development and growth of developed and developing countries. To stimulate investment in RD\&l by private companies, the government resorts to several mechanisms, such as financial and non-financial incentives, such as tax incentives. Thus, this work is aimed at analyzing, through an exploratory research with private companies from various sectors of the Brazilian economy, the use of tax incentives for RD\&l in the private sector, set forth in the main public incentive mechanism for RD\&l enforced by the Federal Government of Brazil - Lei do Bem. The findings show the importance of public policies to promote investment in RD\&l in Brazilian private firms, but also highlight difficulties and improvement suggestions for the use of tax incentives provided for by the Good Law - Lei do Bem, which results in a number far below the expectations of the Federal Government of Brazil.
\end{abstract}

Keywords: r\&d; technological innovation; tax incentives for innovation; good law.

\footnotetext{
1,2 Universidade de São Paulo | USP, Administration Department. Faculty of Economics, Administration and Accounting of Universidade de São Paulo| FEA-USP. Av. Prof. Luciano Gualberto, 908 - FEA Building I - Room E 208. Cidade

Universitária - São Paulo/SP. 'E-mail: rsbragia@usp.br, ²E-mail: sfabiani@gestiona.com.br
} 


\section{I - Introduction}

Technological innovation, carried out from scientific findings and the development of new technologies, represents the main source of economic growth in industrialized countries. In order for these countries, as well as the so-called NICs (Newly Industrialized Countries) to maintain and increase their levels of social and economic development, the main factor is the exploration of new products, processes and services, as well as their respective improvements. To this end, each nation must develop its own system of innovation that seeks integration between government, private companies, universities, research institutes, technology centers and civil society organizations (United Nations, 2005).

In order to stimulate private investment in RD\&l, instruments for encouraging innovative activities have been offered by the government in many countries for several decades. Such instruments are created with the goal of raising the competitiveness of businesses and hence the industry to which they belong. They are both financial incentives, such as lending and granting of non-reimbursable funds, and nonfinancial incentives, such as tax incentives.

In Brazil, between Government Policies and the Tax Law, the Regulatory Act of the National Fund for Scientific and Technological Development - FNDCT (199I), PITCE Industrial,Technological and Foreign Trade Policy (2003), the Innovation Law and the Information Technology Law (2004), and the Good Law (2005) - basis for the analysis carried out in this article on the use, progress and benefits of tax incentives in private Brazilian companies.

In this context, this paper aims at analyzing the use of tax incentives for technological innovation by private companies in the Brazilian market, as well as the main benefits perceived by them and suggested improvements, focusing on the (latest) Annual Report of the Use of Tax Incentives, Base Year 2012 of Law 11.196/2005 (Lei do Bem), the Federal Government's main mechanism to encourage technological innovation in private companies operating in the domestic market. Moreover, by way of background, this paper seeks to analyze the conceptual and historical process of Brazilian incentive mechanisms for technological innovation, as well as the progress of tax legislation for technological innovation in Brazil, through the analysis of the regulatory framework of the national system for innovation and major laws.
In order to achieve the defined goals, a quantitative study has been developed with 26 companies (belonging to the customer base of a consultancy firm specialized in managing tax incentives and financing for innovation) beneficiaries of tax incentives provided for in the Good Law The collection of primary data from private companies through interviews followed the logical structure of the questionnaire entitled "Estudo de Acompanhamento da Lei II.196/2005 Incentivos Fiscais à Inovação Tecnológica" (Appendix). This questionnaire was designed based on the Form to acquire Information about Technological Research Activities and Development of Technological Innovation - FORMP\&D 2012. Secondary data were obtained primarily from the latest official documents of key government agencies, particularly MCTI's Annual Report of the Use of Fiscal Incentives, consolidating the 7th year of implementation of Law no. II.196 (Good Law), whose content includes the results registered by private companies in fiscal year 2012 .

\section{II - Literature Review}

\section{I Technological Innovation and Economic Development}

For Schumpeter (1912), named as the father of innovation studies, the concept of innovation spans five situations, which are (i) the introduction of a new product, which may be new to consumers, or match the new quality of an existing product, (ii) introduction of a new production method, which has not yet been tested by the sector in which the company operates, and not necessarily a scientific discovery, (iii) the opening of a new market where other companies in the same industry have not approached yet, and such a market may or not have existed before, (iv) the conquest of a new source of inputs, again, this source may already exist or have been created, ( $v$ ) establishment of a new industrial organization, either by creating a monopoly, or by the fragmentation of a monopoly.

The concept of technological innovation, which will be used in this article, is that defined and used by the Oslo Manual, which is narrower than the one presented by Schumpeter (19/2). According to the OECD (2004), technological innovations in Technological Product and Processes (TPP) comprise the deployments of technologically new Products and Processes, as well as significant technological improvements in products and processes. For a TPP innovation to be deemed deployed, it must have been introduced in the market (product innovation) or used in the production process (process innovation). 
The recognition of technological innovation as a driving force for the development of companies and countries can be summarized as follows: "Innovation is one of the mantras of contemporary societies. It has been increasingly invoked as a basic mechanism to redeem companies, regions and nations from their chronic economic woes" (Plonski, 2004, p. 93). Increasingly, entrepreneurs, governments, public policy makers and academics have recognized that it is through technological innovation, as thought by Schumpeter, that companies and countries are able to establish the competitive edge to maintain their market position.

\subsection{Incentive Mechanisms to Encourage Innovation in Brazilian Companies}

The instruments for encouraging technological activities in Brazilian companies are both financial incentives, such as lending and granting of non-reimbursable funds, and non-financial incentives, such as tax incentives and grants for postgraduates to work in the companies. In addition to these financial and economic instruments, managerial and technical aids are also being granted to companies (ANPEI, 20I0).

The main difference between tax incentives and direct grant, according to Czarnitzki, Hanel and Rosa (2004), is the neutrality of the tax incentive framework with respect to the industries, sectors and nature of business firms. For the authors, if compared to the selection of projects for direct grants, the main advantage of these programs is the reduction of discretionary decisions involved. For David, Hall and Toole (2000), the choice of projects, in the case of tax incentives, is borne by firms, while for financial incentives, the government chooses the projects and research areas.

The private return can be distinguished in terms of: (a) accumulation of knowledge capital stock, (b) development of competencies at companies that may influence competitiveness in R\&D, and (c) commercial returns from $R \& D$. On the other hand, the social return will depend on the increase of basic science and technologies that facilitate the production of R\&D, the creation of income or rent spillovers, as well as pure knowledge spillovers.

\subsection{Regulatory Framework}

The Brazilian Constitution of 1988 dedicated a separate chapter (Chapter IV) to Science and Technology. Title VIII, destined for social order, regards the role of the State in connection with science and technology (BRAZIL, 1988). The first provision is article 218 which establishes the Brazilian development guidelines for the science and technology sector.
Article 218.The State shall promote and encourage scientific development, research and technological expertise.

Article 219. The domestic market is part of the national heritage and will be encouraged to facilitate the cultural and socio-economic development, as well as the welfare of the population and the technological autonomy of the country, under a federal law.

A set of laws and decrees of incentive and support to STI (defined as innovation policy), as well as constitutional (1988 Constitution) and legal frameworks were drafted based on these articles, represented by the Innovation Law and, especially, the Good Law, based on the "Innovation and Legal Security" workshop held at FIESP - São Paulo, sponsored by the Center for Management and Strategic Studies, linked to MCTI, and the Brazilian Agency for Industrial Development $(A B D I)$, linked to the Ministry of Development, Industry and Foreign Trade (MDIC), in October 2006.

\subsection{Innovation Law - Law no. 10.973/2004}

The Innovation Law no. 10.973 was approved on December 2, 2004, but only on October II, 2005, it was regulated by Decree-Law no. 5.563. This Law seeks to promote the country's technological autonomy and industrial development by creating a scenario compatible with scientific and technological development, and innovation encouragement, considering public institutions, companies and inventors/researchers. It also aims at creating an enabling environment for strategic partnerships between universities, technological institutes and companies, having knowledge as a central element.

The "Innovation Law" represents a broad set of measures. Its goal is to "expand and expedite the transfer of knowledge generated in academia for its appropriation by the productive sector, encouraging a culture of innovation and contributing to the industrial development of the country" (MCTI, 2006).

\subsection{The Good Law - Law no. I I.196/2005}

Law no. I I.196/2005 - known as the Good Law - establishes the Special Tax Regime for the Information Technology Services Export Platform - REPES, the Special Regime of Acquisition of Capital Goods for Export Companies RECAP and the Digital Inclusion Program, and also provides for tax incentives for technological innovation. 
Decree no. 5.798/2006 regulates tax incentives for technology research and innovation development activities, under Articles 17-26 of the Law at issue, whereas the main mechanism is the deduction of taxes from the entry of outlays on technological innovation R\&D and from the subsidy provided through funding agencies, to the remuneration of teachers and doctors at companies. It is noteworthy that FINEP has a special line of credit for hiring researchers, with grants of up to $60 \%$ of the remuneration.

Another positive point of the Good Law concerns the ascertainment of net income. There is a deduction corresponding to the sum of outlays performed during the ascertainment period with technological research and development of technological innovation, the R\&D agreements executed with Universities, Research Institutes and independent inventors are included here.

There is an accelerated amortization of the expenditures related to the purchase of intangible assets, through deduction as operating expense or costs and linked solely to technological research and development of technological innovation, classifiable as deferred asset of the beneficiary, for calculating corporate income tax, the R\&D results obtained through partnerships with STIs are included here. There is also the withholding tax credit on income that falls upon paid amounts, remitted or credited to beneficiaries resident or domiciled abroad, as royalties, from technical and scientific assistance and specialized services linked to a minimum outlays provided for in technology transfer agreements in which the STIs directly fit in.

\section{III - Analysis of Results}

\section{I Analysis of the Annual Report on the Use of Tax Incentives}

Presented below is the Analysis of the Annual Report on the Use of Tax Incentives, consolidating the 7th year of implementation of the Good Law, whose content includes the results registered in fiscal year 2012 .

In FY 20I I, the MCTI registered I,042 forms of legal entities (companies) who reported having benefited from tax incentives, an increase of $8.3 \%$ as compared to $20 \mathrm{II}$, when 962 companies delivered said forms.

In Chart $0 \mathrm{I}$, it is possible to note that the number of companies that have joined the program of tax incentives for technology research activities and development of technological innovation (lines A and B) has increased year after year, whose lines of projections prove these developments. Their analysis shows a reduction in the number of non-classified companies from $16 \%$ in 2011 to $21 \%$ in 2012 . It is noteworthy that the total number of participating companies $(1,042)$ consists of 787 classified companies, 218 non-classified companies, 37 companies in other situations.

\section{Progress in the No. of Participating vs. Classified Companies}

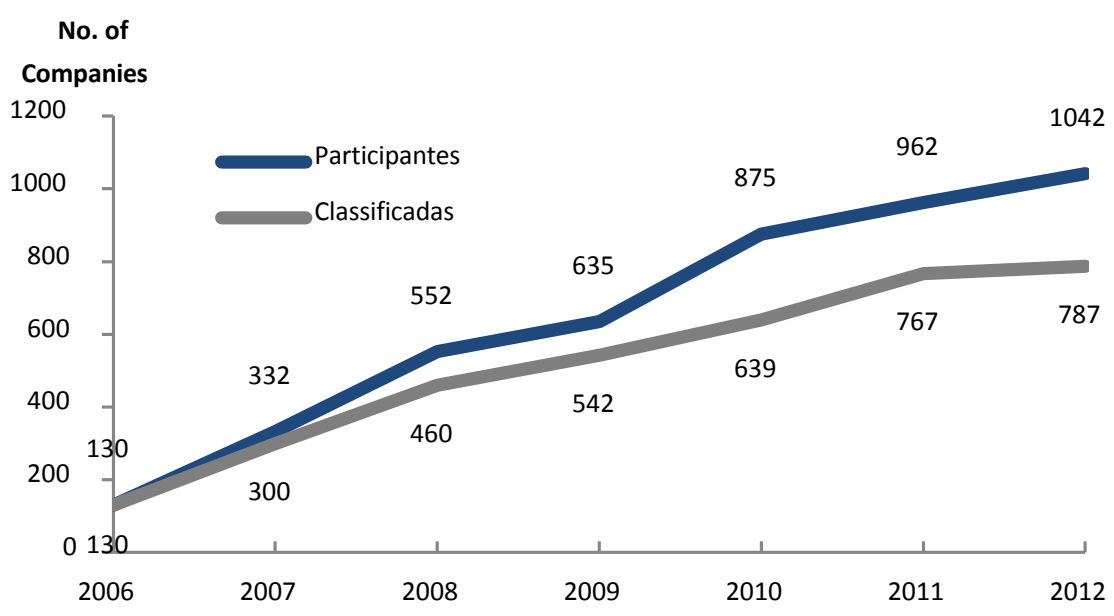

Chart 01: Number of participating/classified companies Adapted MCTI (20I2)

ISSN: 07 I8-2724. (http://www.jotmi.org) 
Table 01 presents the distribution of firms based on the NCEA, the calculation bases and their tax relieves for corporate income tax and social contribution, as well as the benefits of a $50 \% \mathrm{IPI}$ reduction for the acquisition of machinery, equipment, appliances and exclusive R\&D instruments, and the reduction to zero of the income tax rate on foreign remittances destined for the payment of records required in maintaining trademarks, patents and cultivars.

Data from MCTI's Annual Report - Base Year 2012 show that the number of companies opting for the enjoyment of tax incentives under the Good Law continues to grow moderately. In 201I, MCTI received 962 forms, in 2012, I,042 companies were registered, i.e., a growth of $8 \%$, and the absolute amount of approved companies was also higher: 787 in 2012 versus 767 in $201 \mathrm{l}$. However, there was an increase in the percentage of non-classified companies, from $16 \%$ ( 157 companies) in 2011 to $21 \%$ ( 218 companies) in 2012, which shows some inconsistencies in the reports submitted by the companies to MCTI, as per the analysis developed by the body, namely: (I) conceptual and qualitative problems in the description of the projects, and (2) lack of correspondence between expenditures and their projects.

\subsection{Perception of private companies about innovation and use of incentive policies in Brazil}

Considering that the main objective of the study is connected to the corporate sector, 26 companies were elected to represent the following sectors of the economy, in accordance with the national classification of economic activities (NCEA), which is the same criteria adopted by MCTI for the preparation of the Annual Report on the Use of Tax Incentives under the Good Law.

\begin{tabular}{|c|c|c|c|c|c|c|c|c|}
\hline $\begin{array}{l}\text { DISTRIBUTION OF } \\
\text { COMPANIES AND } \\
\text { BENEFITS BY SECTOR }\end{array}$ & & & $*(\times 1.000)$ & & & & & \\
\hline Sector & $\begin{array}{l}\text { No. of } \\
\text { Companies } \\
\text { Approved }\end{array}$ & $\begin{array}{l}\text { Calculation } \\
\text { Base (Income } \\
\text { Tax }+ \text { Social } \\
\text { Contribution } \\
\text { on Net Profit)* }\end{array}$ & $\begin{array}{l}\text { Social } \\
\text { contribution } \\
\text { on Net Profit } \\
(9 \%)^{*} \\
\text { (a) }\end{array}$ & $\begin{array}{l}\text { Income Tax } \\
(25 \%)^{*} \\
\text { (b) }\end{array}$ & $\begin{array}{l}\text { Income Tax* } \\
\text { (c) }\end{array}$ & $\begin{array}{l}\text { Ext } \\
\text { Income } \\
\text { Tax* } \\
\text { (d) }\end{array}$ & $\begin{array}{l}\text { Total* } \\
(a+b+c+d)\end{array}$ & Average* \\
\hline I.Agribusiness & 11 & 53,271 & 4,794 & 13,318 & 0 & 0 & 18,112 & $\mathrm{I}, 647$ \\
\hline 2. Food & 67 & $|3|, 9||$ & II,872 & 32,978 & 0 & 0 & 44,850 & 669 \\
\hline 3. Consumer Goods & 49 & 258,047 & 23,224 & 64,512 & 14 & 4,127 & 91,877 & I,875 \\
\hline 4. Civil Construction & 11 & 53,729 & 4,836 & 13,432 & 0 & 0 & 18,268 & $|, 66|$ \\
\hline $\begin{array}{l}\text { 5. Electrical and } \\
\text { Electronics }\end{array}$ & 57 & 283,072 & 25,477 & 70,768 & 1,043 & 0 & 97,288 & I,707 \\
\hline 6. Pharmaceutics & 42 & 291,885 & 26,270 & 72,971 & 0 & 0 & 99,241 & 2,363 \\
\hline $\begin{array}{l}\text { 7. Mechanics/ } \\
\text { Transportation }\end{array}$ & 125 & 753,854 & 67,847 & 188,463 & 0 & 0 & 256,310 & 2,050 \\
\hline 8. Metallurgy & 47 & 101,166 & 9,105 & 25,291 & 0 & 0 & 34,396 & 732 \\
\hline 9. Mining & 18 & 95,121 & 8,561 & 23,780 & 0 & 0 & 32,341 & $\mathrm{I}, 797$ \\
\hline 10. Furniture & 22 & 12,378 & 1,114 & 3,094 & 0 & 0 & 4,208 & 191 \\
\hline II. Pulp and Paper & 17 & 29,579 & 2,662 & 7,395 & 0 & 0 & 10,057 & 592 \\
\hline 12. Petro (chemic) & 99 & 238,843 & 21,496 & 59,711 & 194 & 0 & 81,401 & 822 \\
\hline 14. Software & 65 & 204,354 & 18,392 & 51,088 & 7 & 0 & 69,488 & 1,069 \\
\hline I5. Telecommunication & 1 & 4,660 & 419 & 1,165 & 0 & 0 & $\mathrm{I}, 584$ & $\mathrm{I}, 584$ \\
\hline 16. Textile & 6 & 4,845 & 436 & $\mid, 211$ & 0 & 0 & 1,647 & 275 \\
\hline 17. Other Industries & 150 & 535,854 & 48,227 & 133,964 & 69 & 4,869 & 187,129 & $\mathrm{I}, 248$ \\
\hline Total & 787 & $3,052,568$ & 274,73 I & 763,142 & 1,328 & 8,997 & $1,048,198$ & I,332 \\
\hline
\end{tabular}


It is worth remembering that $100 \%$ of the companies participating in this study have already used the tax incentives provided for in the Good Law at least once and, therefore, in addition to the fact that the sampling is not probabilistic, the analyzes the responses cannot be generalized in any way. In addition to the segmentation of firms by economic activity, certain aspects were considered, such as the origin of the company's controlling shareholders and its size with regard to the number of employees with employment relationship. $77 \%$ of companies surveyed have national controlling shareholders.

Regarding the number of researchers, all companies have more than 50 employees with employment relationship, whereas, over $80 \%$ have 250 or more employees.

The first analysis regarding the vision of businesses on RD\&l, deals with the existence of an area formally responsible, being also included in the company's organizational chart for the management of R\&D activities and innovation. Nearly $70 \%$ of companies surveyed now have a formal R\&D area. Here we can identify the first positive impact of the Good Law, because all 8 companies that so far have lacked an R\&D area have shown strong interest in formalizing such an area, not only to meet the legal requirements, but also due to the strategic importance for the management of technological innovation projects.

On the other hand, with regard to the restriction of the Good Law for use of tax incentives for technological innovation due to tax loss in the base year of the investments, only 3 companies, that is, $12 \%$ of the total incurred in this situation. Nevertheless, almost all respondents cited this constraint as the main flaw of the Good Law, because despite continued investments in R\&D, in a moment of difficulty endured by the company or industry that generates a tax loss, the company loses the tax benefit, which, under no circumstance, can be recovered. In short, the repeal of this restriction is among the main proposals for the improvement of tax incentives for innovation, provided for in the Good Law.

Regarding the influence of tax incentives for innovation on the level of investment in R\&D of companies, according to $54 \%$ of the respondents, the Good Law represents an opportunity to invest more resources in R\&D in previous years. However, $27 \%$ of the companies believe that the Good Law does not influence the level of investment in $R \& D$, as these are determined almost exclusively by market and competition aspects. Chart 4 shows the relationship of factors that influence the level of investment in the companies surveyed.
Although the correlation is not perfect, most companies with little maturity in terms of RD\&I practices and structure have demonstrated the positive impact of the Good Law in turning RD\&l activities into strategy and consolidated and long-term processes. As the main benefit of the Good Law, companies with consolidated RD\&l structures had the possibility of increasing the investments in technological innovation projects. Finally, strongly market-oriented companies reported little influence of the Good Law in deciding the R\&D investments.

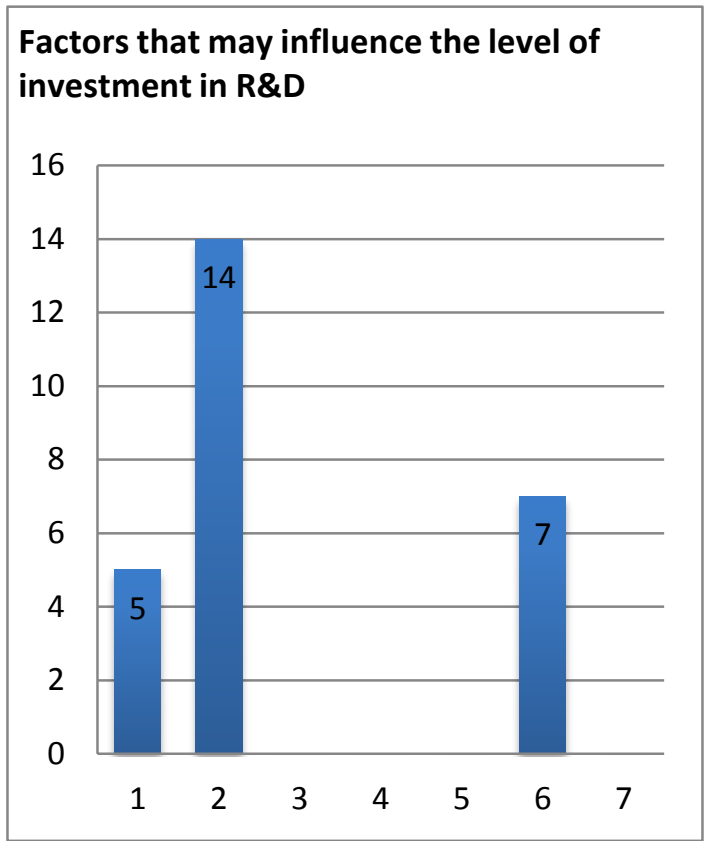

Legend Chart 4:

I. Good Law contributed so that the R\&D.

2. GL opportunity invest more resources R\&D.

3. GL influences there is pressure technical leadership

4. GL relevant decision in Brazil.

5. GL not influence because not possible use consecutive years.

6. GL not influence because investments influenced by market.

7. GL not influence due obligations between subsidiary and parent. 
Also with regard to the influence of tax incentives for innovation in the R\&D investment decisions, in $50 \%$ of the cases analyzed, the Good Law helped to render more visibility to the R\&D area in the company, especially in companies where the RD\&l subject was recent. On the other hand, for some companies in which the innovation process has reached maturity, the strategy and planning will work independently of the incentives granted by the Good Law. With respect to the approval of the FORMP\&D - Form for Information on the Activities of Technological Research and Development of Technological Innovation - FORMP\&D, submitted to MCTI by companies that chose to use the tax incentives set out in Chapter 3 (Articles 17-26) of the Good Law, only $2(8 \%)$ interviewed companies have already had projects rejected by MCTI, and the reasons were: (i) third party services (universities, research institutions, independent inventors, micro enterprises and small businesses) not aligned to the requirements of the Good Law, and (ii) acquisition of exclusive RD\&l equipment, which probably did not meet legal requirements.

The next section deals with the use of each of the 9 tax incentives provided for in the Good Law As seen in Chart 5 , the main tax incentive is a deduction of up to $60 \%$ of the social contribution calculation basis, and of the sum of expenditures made during the reference year for ascertaining the net income, being used by 100\% of the companies interviewed.Then, there is the full depreciation of equipment and other tangible assets intended for R\&D, with $73 \%$ of the companies surveyed, and the additional deduction of up to $20 \%$ in case of increased number of researchers employed in the reference year, in percentage above $5 \%$, with regard to the average of researchers with employment relationship in the previous year. In fourth place, with $46 \%$, the $50 \%$ IPI reduction levied on equipment, machinery and imported instruments intended for R\&D. We note that the rest of incentives is underused mainly due to the low occurrence and to the small value of the benefit.
The analysis of Chart 6 allows us to conclude that among the reasons listed to justify the non-use of tax incentives, the main one consists of identifying uncertainty in process innovation, mentioned by 12 companies ( $46 \%$ ), followed by the insecurity in only entering the invoice when the project is partially or fully outsourced, with $53 \%$, and the researcher exclusivity issue, in $31 \%$ of the companies.

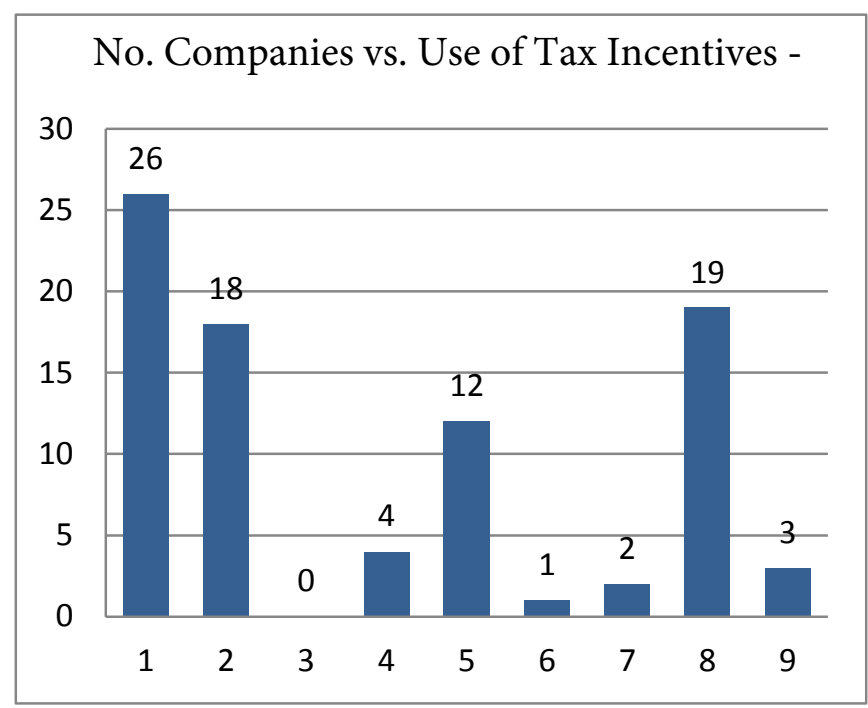

Legend Chart 5:

I. Deduction $60 \%$ of the sum of expenditures

2. Up to $20 \%$ increased number researchers (5\%)

3. Up to $10 \%$, number of in up to $5 \%$.

4. Up to $20 \%$, in the case of patent.

$5.50 \%$ of IPI equipment for R\&D.

6. Withholding Tax Credit technology payments abroad.

7. Reduction withholding tax rate trademarks, patents.

8. Integral depreciation of equipment for R\&D.

9. Accelerated amortization: intangible assets R\&D. 
As for the items to be improved by legislation, including the addition of Law no. II.196/2005, of Decree no. 5.798/2006, Normative Instruction no. I.187/20II of Brazil's Federal Revenue Office, $85 \%$ of the companies interviewed questioned the required exclusion of the project management and administration team from the operating expenses, as they are essential for the implementation. $77 \%$ of companies mentioned the difficulty in establishing partnerships with STIs (Science and Technology Institutions) and universities for the development of RD\&I projects, while $50 \%$ of companies suggested the repeal of the mandatory submission of 2 Debt Clearance Certificates per year, that is, one for each half of the fiscal year.
Ultimately, several proposals were submitted for improving the tax incentives for innovation (Lei do Bem). It becomes evident that the main points to be improved are: (i) to increase the deduction from $60 \%$ to $100 \%$ of the sum of expenditures on R\&D, mentioned by $88 \%$ of companies, (ii) to allow the recovery of benefits in later periods in case of damages or exceed the amount of actual profits, chosen by $85 \%$ of the respondents, and (iii) additional deduction of $80 \%$ in case of an increased number of researchers, instead of (up to) the current $20 \%$, cited in $77 \%$ of cases.

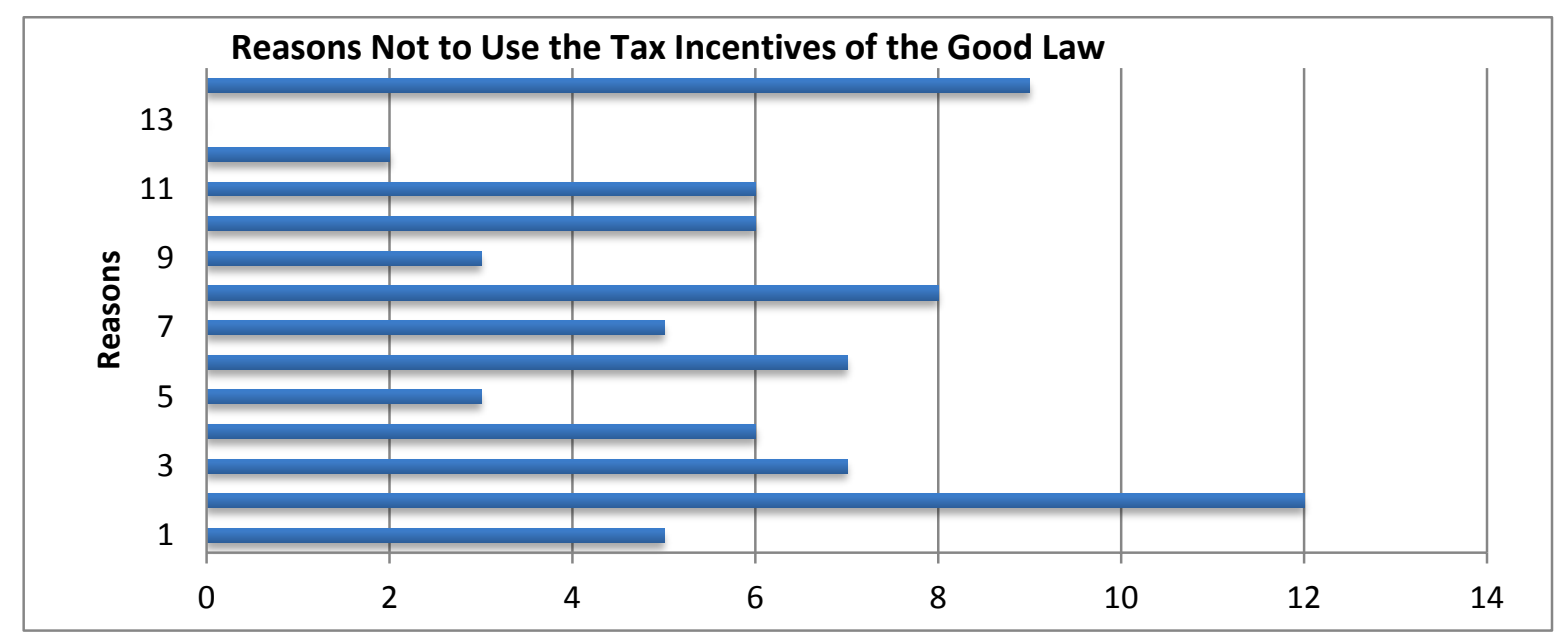

Legend Chart 6:

I. Uncertainty if the company's

2. Uncertainty identification of process innovation.

3. Difficulty ensuring equipment is $R \& D$ area

4. Not use IPI reduction because other policies.

5. Bureaucracy required is little financial perspective.

6. Tax incentive is little as opposed labor charges.

7. High turnover of staff use incentives.

8. Incentive not be used impossible ensure activities R\&D.

9. The patent has not been granted.

10. Tax incentive on patent granting is very little.

II. Link between the patent and the project delays.

12. Incentive patents was not used company headquartered abroad.

13. Legal uncertainty.

14. Insecurity in project is partially or fully outsourced. 
In general, the interviewed companies were quite favorable to the technological innovation topic, particularly recognizing its relevance to increase competitiveness, especially within the domestic market. However, although they recognize the importance of innovation, the companies also show how far apart they see themselves achieving higher levels of technological sophistication. Parameters range from the numbers on the percentage of investments in R\&D by the private sector, through the number of masters and doctors working in industries and the number of patents generated. Another consensus view is that Brazilian companies, in general, have chosen not to take risks, and invest in R\&D is making a bet as there are competitors around the world that may be developing the same products and the same technology they are researching. And often, these competitors have a more innovation-oriented environment, ranging from better infrastructure, more focused government policies and more sophisticated internal technical and managerial skills.

Certain policies may be a solution to reduce the uncertainty of private investment, such as the public policy of incentives for technological innovation, spearheaded by the Good Law, i.e., sharing the risk of an R\&D development with the Government. In return, this will generate jobs, higher levels of export and all the consequences arising from this activity. The company's return, on the other hand, consists of profits and greater market competitiveness.

Although the Good Law has generated interesting benefits regarding the development of technological innovation projects for companies in virtually every sector of the economy, the perception of the business sector is that there is no proper coordination and harmony between the different government spheres, which tends to generate an inefficient system for the proposal of contributing to the technological development of companies.

The research identified that the major concerns of large companies are the acquisition of machinery and equipment, human resources training and qualification, and development of products and processes. Moreover, the survey indicated that in small companies, the emphasis was on placing innovative products on the market, especially companies from business incubators. In addition, customers, equipment suppliers, inputs, components and software are still the main partners of Brazilian companies for technology development. While companies recognize the importance of technological innovation for competitiveness, it appears in the background, behind other demands considered more important, such as capital, Government (tax), domestic economy, infrastructure and human capital.
The interaction between private companies and university and/or science and technology institutions is still very low. According to the companies, in addition to the huge bureaucracy to formalize the partnership, the universities concentrate their efforts on the training of Master and $\mathrm{PhD}$ professors, and much of their research is unrelated to the interests of companies, and the major concern was the formation of the researcher, which preserved this gap between companies and science and technology institutions.

\subsection{Vision and Innuendo of Companies on the Use of Tax Incentives of the Good Law}

The analysis of questionnaires and interviews with the 26 companies of major sectors of the Brazilian economy with regard to the use of tax incentives for technological innovation provided for in the Good Law allowed the following conclusions:

- From the approximate amount invested in R\&D, over $75 \%$ is held domestically, primarily in their own human resources. According to more than $50 \%$ of the companies, the tax relief of the Good Law is seen in the company as an opportunity to invest more in $R \& D$ resources in later years,

- As regards the non-use of tax incentives, the uncertainty in the identification of process innovation was cited as a reason by $46 \%$ of companies surveyed,

- Regarding the FORMP\&D delivered to MCTI, less than $10 \%$ of companies have had some kind of rejection by the MCTI over the years of use of incentives, and main reasons were (i) projects not aligned to the concept of innovation under the Good Law and (ii) inclusion of equipment (not exclusive) for R\&D,

-With regard to the amplitude and type of innovation, almost $60 \%$ of the projects are focused on adding new features or characteristics to the product, and more than $70 \%$ of companies indicated such projects as innovations only for the company, highlighting the low level of innovation of most projects developed by the companies at issue,

- The analysis of questionnaires also revealed that the main criticisms regarding the requirements for the use of the benefits provided by the Good Law were: (i) required exclusion of operating expenses related to administration and project management team, mentioned by $85 \%$ of companies, partnerships with universities and STIs, cited in $77 \%$ of cases, and (iii) required submission of two Debt Clearance Certificates or Liability Certificate with Clearance Effects, in $50 \%$ of cases, 
- When compared to other instruments in support of technological innovation, such as the Information Technology Law, tax incentives for partnerships with STIs, Financing of Research Projects in partnership with Universities and Research Institute (FUNTEC), repayable financing (FINEP and BNDES), economic grant (FINEP) and financial support from Research Support Foundations (FAPs), the completeness and efficiency of the Good Law becomes evident as the main public incentive mechanism for technological innovation in Brazil.

- Finally, the main improvements suggested by the interviewed companies were: (i) $100 \%$ deduction of the sum of outlays on R\&D, (ii) permission to use the benefits in later periods when there is damage or when exceeding the amount of actual profits, (iii) permission to deduct a further $80 \%$ in case of an increased number of researchers, and (iv) permission to transfer the equipment benefited from the IPI incentive after I or 2 years.

\section{IV - Conclusions and Final Thoughts}

Technological innovation through science, research and development is an essential instrument for Brazil to promote its economic development, build and consolidate its technological sovereignty, and actually consolidate a sustainable development model capable of meeting the aspirations of society as a whole.

At present, Brazil already has a favorable environment for companies to feel encouraged to invest more in RD\&l when considering the existence of a consolidated legal framework, suitable institutions, solid industrial structure and the availability of financial resources in all government spheres. Indeed, in the case of the Brazilian government, even with the threats of an international economic crisis, it got to the point of expanding the instruments for the support of research, development and technological innovation activities of companies to a point in which, in the last five years, the expansion of credit has nearly doubled in value. However, few companies know of the existence of such mechanisms and, many of those which already know them, choose not to use them for various reasons.

The continuous growth in the number of companies under the Good Law reveals that the use of tax incentives for technological innovation establishes and consolidates the Good Law as a new institutional resource, whose instrument has contributed for national companies to become efficient and competitive to face the fierce international competition due to market globalization.
However, an analysis of private companies that already use the incentives of the Good Law indicate the need for a review on current mechanisms and certain suggestions for improving this instrument. The main benefit of the Good Law, the deduction of expenditures on R\&D, stimulates innovation only when there is profit in the companies. Meanwhile, insecurity, especially in the identification of process innovation, is another concept that needs to be revised, because it may shift the investments related only to product development projects.

Regarding the improvement of current mechanisms, the permission to use the benefits in later periods in case of tax losses and the permission to transfer R\&D equipment to productive areas after a certain period are among the main demands of said companies.

Despite the continued growth in the number of companies using the Good Law, when the Brazilian market is considered, the percentage of companies that benefit from these incentives is still very small, partly due to the two main restrictions of the Good Law: only companies included in the actual profits tax regime and the obligation of ascertaining taxable income in the base year at issue. In addition, the legal uncertainty and lack of knowledge on the part of Brazilian businessmen are other aspects that help explain this phenomenon.

As limitations, one should understand that, with regard to the primary data, the study did not adequately explore all major agents of the Triple Helix, i.e., the interrelation between universities (and other science and research institutions), private companies and the government. Other government agencies, associations and institutes would need to have been included in the study, as well as a greater number of private companies in order to take account of a representative sample of the different segments of the Brazilian economy. With regard to the primary data, a more robust methodology could have been used for the quantitative analysis of information, even when considering the limitations of the sample.

In the second half of 2013, IBGE will provide the results of PINTEC 20II - which will bring the most recent data on Technological Innovation for the 2009-20II period in Brazil. A comparative study of data from PINTEC 2011 combined with the data from this study may contribute in understanding the progress of technological innovation in Brazil. 


\section{References}

ALMEIDA, F.A.S., Kruglianskas, I., Cota, M.F.M., Sbragia, R., Guimarães, A.T.R. (2008). Política de inovação tecnológica no Brasil: uma análise da gestão orçamentária e financeira dos fundos setoriais. Revista de Informação Contábil, v. 2, 102-116.

ARRUDA, Mauro, Vermulm, R., Hollanda, Sandra. (2006). Inovação tecnológica no Brasil: a indústria em busca da competitividade global, II7.

CASSIOLATO, J.E., Lastres, H.M.M. (1998). Inovação, globalização e novas políticas desenvolvimento industrial e tecnológico. Technical Note 21/98, Rio de Janeiro

CASTRO, R.C.G. (2005). Os números da inovação no Brasil. USP Journal, São Paulo.

CORDER, S., Salles-Filho, S. (2006). Aspectos conceituais do financiamento à inovação. Revista Brasileira de Inovação, v.5, I .

DUDZIAK, E.A. (2007). Lei de inovação e pesquisa acadêmica: o caso PEA.Thesis (Doctorate), São Paulo.

KRUGLIANSKAS, I., Mathias-Pereira, J. (2005). Um enfoque sobre a lei de inovação tecnológica do Brasil. RAP. Revista de Administração Pública, v.5, São Paulo.

LICHTENBERG, F., Siegel, D. (1991). The impact of R\&D investment on productivity. Economic inquiry. v. 29.

MCTI, (20I2). Relatório anual da utilização dos incentivos fiscais ano base 2012. Capítulo III da Lei do Bem - Lei No. II.196/05. http://www.mct.gov.br/upd_blob/0229/22978I. pdf [Accessed February, 2014]

PLONSKI, Guilherme Ary. Bases para um movimento pela inovação tecnológica no Brasil. São Paulo em Perspectiva, v.19, n.I jan./mar. 2005, p.25-33.

PORTER, Michael. E. (1995). A vantagem competitiva das nações, Rio de Janeiro.

RESENDE, S. M. (2006). Evolução da Política Nacional de Ciência, Tecnologia e Inovação e dos seus instrumentos de apoio. In $3^{\text {a }}$. Conferência Nacional de Ciência, Tecnologia e Inovação. Síntese das conclusões e recomendações, Brasília.

SALLES FILHO, Sergio. (2003). Política de ciência e tecnologia no II PBDCT. Revista Brasileira de Inovação, Rio de Janeiro.
SBRAGIA, R., Krugliankas, I, Arango-Alzate, T., (200I). Empresas Inovadoras no Brasil: uma Proposição de Tipologia e Características Associadas. Série de working papers do departamento de administração FEA-USP, São Paulo.

SCHUMPETER, J. (1998). Teoria do desenvolvimento econômico. 3.ed., São Paulo.

SCHWARTZMAN, S. 1993. Ciência \& tecnologia no Brasil: uma nova política para um mundo global. Série Ciência e Tecnologia no Brasil, São Paulo.

TIRONI, L.F., Koeller, P. (2006). Financiamento público à inovação segundo a pesquisa industrial de inovação tecnológica (pintec), Brasília.

WEISZ, J. (2006). Mecanismos de apoio à inovação tecnológica. 2 ed., Brasília. 